\title{
Challenges of Electronic Information Management in Nigerian University Libraries
}

\author{
Rev'd Obiroa Nwosu, Ifeka, E. Okeke, Efe Francis Ejedafiru \\ Department of Library and Information Science, Nnamdi Azikiwe Unviversity, Anambra State. Nigeria. \\ Department of Library and Information Science, Nnamdi Azikiwe Unviversity, Anambra State. -Nigeria \\ Department of Library and Information Science, Delta State University, Abraka.-Nigeria
}

\begin{abstract}
The study is intended to establish the best ways of managing electronic information and improving library services using Delta State University of Abraka and University of Benin as a case study. The survey research design was adopted, the systems administrators were interviewed and the researchers also observed ICTs facilities on ground in the two universities. Studies have shown that, even academic libraries with sizable budgets are having difficulty in coping with the incessant changes in electronic information. More technologies and methods are needed to manage, filter, organize and summarize electronic information sources. Electronic information services are gradually becoming the most likely use services in libraries. This paper is an overview of the challenges of electronic information management in university libraries, issues ranging from management style, frequent changes in technologies, financial constraints, availability of e-books and e-journals and constraints to the management of e-resources. It concludes by recommending actions that need to be taken if the challenges are to be fully addressed.
\end{abstract}

\section{Introduction}

University libraries are the "pivot" upon which learning, teaching and research roles of the universities revolved. Therefore it must produce services that are in demand, it must state its general objective in terms that apply to all academic libraries, but also in specific terms aimed at service to the changing information needs of the $21^{\text {st }}$ century library users. To say that the objective of the university library is to provide the right book to the right reader at the right time is not enough. It may be more accurate to state its objectives as being (i) to provide all needed information irrespective of formats to meet the needs of all library patrons (ii) to attract highly qualified staff to manage technology driven information society.

It is paramount to note that contemporary university library service provision in the $21^{\text {st }}$ century is highly influential and predominated by the dynamics of electronic resources which are enormous. This electronic information system has a prompting mechanism, which gears up all libraries of the world to become active members of the world system. Hence, users have their information needs met through a number of formats. They need not visit the physical library to use print formats, but through network can stay at home or the office and access online library resources and service. The users can access electronic services from their homes, and offices and the library can also conveniently get usage statistics of their resources which is difficult with the print resources (Aleraraiye, 2005).

Tonta (2004) postulated that owning information sources "just in case" users might need them is no longer the dominant method of collection development in libraries and information centres. Instead, information centres concentrate on providing "just in time" access to electronic resources should the users need them.

Networked information services are gradually becoming the most likely use services in university libraries. What should university libraries in Nigeria do to cope with these challenges? How can this information be managed? What types of management style, if any, should be expected, what are their coping strategies with frequent changes in electronic information, and the financial consequences in this electronic information era. These form the basis for the study.

\section{Review Of Related Literature}

Electronic information management is the management of information that is recorded on printed or electronic media using electronic hardware, software and networks (Tonta, 2004). It includes the description of strategies processes, infrastructure, information requirements as well as making economic, legal and administrative policies of electronic information. Studies have shown that university library have applied technology to information problems, and also attempted to use machine-engineering methods to turn data into something of use on computers. In line with this, Sen in Abubakar (2010) observes that with the advent of computers, the nature of libraries has changed dramatically. It is imperative to note that an attitudinal change that occurred among university librarians early in the $21^{\text {st }}$ century, when developments in the publishing world 
provided information resources in electronic formats call for managerial skills to properly managed e- resources in university libraries.

The advent of Information and Communication Technology (ICTs) has shifted the attention of university libraries to acquisition of electronic information, even though the printed media which form the backbone of libraries are still provided. Infact, new technologies do not necessary supplant the old ones. Hence, information published on different media (paper, microfiche, CD-ROM, etc) will co-exist for quite sometimes.

In a nutshell, university libraries managing information need sound IT support to integrate contents with computer and communication technologies. Abubaka (2010) opined that in advance countries the paradigm shift in ITs has led to dramatic changes in library collections from traditional print resources to electronic resources, where a greater percentage of the budget of most libraries is spent on e-resources such as e-book, ejournal as well as online and subject databases. In fact, information seeking and use is now mostly tailored towards electronic format.

Ironically, university libraries in Nigeria seem to be lacking behind in this dispensation. Aleraiye (2005) lead credence to this when he observed that electronic resources are just emerging in libraries especially the academic libraries where automation has reached an advanced stage. Above all, the pervasive growth of the Internet and the world wide web has created opportunities for a wide variety of electronic resources which are fast becoming the dominant medium of scholarly communication, and which no one library can acquire alone(Bozimo,2011). Hence, Davenport offers the following general guidelines when investing in new technologies:

a) A high degree of network interconnectedness facilitates the exchange of information in organisation

b) Knowledge and information workers require personal computers or workstations and desktop

c) Effective information management increasingly involves providing network access to internal information repositories with many CD-based database;

d) The effective management of organizational information environments increasingly demand network management software.

e) For external information access and communications, use of the internet is increasingly becoming a necessity; and

f) For some companies, the World Wide Web can be a new means of organising and accessing information (Davanport, 1997).

A cursory look at the above indicate that Nigeria university library have a major role to play in this dispensation. Therefore, building ICT infrastructure in Nigerian universities should be seen as a $21^{\text {st }}$ century necessity rather than optional directive to foster economic growth (Ejedafiru, 2010). It is not very clear, if university libraries will not be sole responsible for the preservation and archival of electronic information sources for various reasons. There is a consensus that electronic resources are cheaper to store in large volumes and occupy much less space. The key question here is, of course for Nigerian universities to grapple with the above general guideline, albeit in an environment of very stringent resources constraints. And also decide how to manage and coupe with the influx of electronic information resources.

As more information sources available to university libraries are born digital and publicly accessible by library users through the internet, the relative importance of the management of electronic information, personnel or organization also increases tremendously. This makes the management and retrieval of information from large quantities of electronic sources all the more important to all academic libraries.

There is need for libraries and librarians in particular to manage electronic information successfully. Hence, Alvin Toffler (1992) postulated that the ignorant of the future are not going to be the ones who do not know how to read and write (illiterates) but those who do not know how to find and get access to relevant information ("so called information illiterates"). Consider by many people as the next stage of ("literacy, information literacy includes ability to handle hardware and software (computers, networks, web, etc) used to find information as well (Tonta, 2004).

Management of electronic information that is based on "copying" also engenders heated debate on issues of access and copyright for electronic information. The integrity and authenticity of electronic information becomes more difficult to ascertain. In the light of this, more research is needed to uniquely identify digital objects for description as well as for electronic by means of electronic copyright management systems (ECM). Hedstron (1998) postulated that such unresolved issues make digital preservation a "time bomb" for electronic information management.

Clearly, the views for users of electronic resources are favourable and provide some justification for the financial investment in installing and maintaining these systems in academic libraries. Adams (1995) has argues that electric information network has opened up a new vista to African researchers, academics and students as well technocrats. Adams (1997) and Fall (1996) in their studies have argues that African countries are already embracing the current information and communication technology. This has been corroborated by Teferra (2004) and Gbaje (2007). 


\section{Methodology}

Survey research design was used for this study. Interviews and observations were used as instruments. Interviews were conducted with the system administrators of the two university libraries under study. However, structured interview gathered information from the system administrators on method or possible type of management style, method of coping with the frequent changes in technologies, financial implication, and problems of managing electronic resources. The interview also elicited information in level of power supply availability of e-journal facilities for accessing the e-resources such as e-journal, e-books etc.

\section{Findings And Discussion}

Two university libraries were used for this study, first university of Benin, own by Federal Government of Nigeria while the other, Delta State University, Abraka own by Delta State government. The two systems administrators of the libraries were interviewed, the justification for using them was that both of them had first degree in computer science and masters in library and information science as their highest educational qualification. And both of them have worked in the library for more than 10 years each. And being the heads of the system session would be in best positions to speak on challenges of electronic information management in these libraries. since the system administrators were well qualifies in term of maturity, qualification and wealth of experience.

\section{Management Of Electronic Information Resources}

The two system librarians were interviewed on adequacy of policy on management of e-resources: the general response from the two librarians was that there was no written policy on management of e-resources. But the need to satisfy user's information needs, through electronic resources cannot be overemphasised at this $21^{\text {st }}$ century. They agreed that e-resources offer their library opportunities for collaboration, flexibility, specialization and economics of scale that are not just possible for a library operating in isolation. Efforts to improve and reform university libraries in Nigeria management require clear and specific objective, guidelines and time-bound resources hence no single management style could be single handily adopted.

\section{State of Funding}

From their responses, it is a truism that each of these university libraries have been submerged by the financial challenges of electronic resources. The university of Benin librarian, been a federal university admitted that though $10 \%$ of recurrent expenditure of the university is given to the library, but this amount is not adequate and very unpredictable. The system librarian noted that except for the Tertiary Education Tax Fund: Library intervention Programme such as NULIB the library would have been in serious financial difficulties.

On the other hand, the system librarian in Delta State University library observe that there is policy that $5 \%$ of recurrent expenditure of the university should be allocated to the library, because of the fact that it is a state university. The system administrator observed that the poor funding has serious effects on management and acquisition of electronic information. Onokerhoraye (2007) collaborated this when he observed that the declining financial resources available to Nigerian universities, coupled with the expansion of enrolment, virtually all universities in Nigeria have been at a standstill in terms of new construction and capital development.

\section{Amount Spend On Electronic Information}

None of the libraries have accurate record of how much was spent to acquire or subscribe to databases in the recent years. This is to confirm that the parent bodies of the libraries have not done much rather the few efforts were made by ETF or other donor organizations. The university of Benin librarian noted that the library is a member of Nigerian University Libraries Consortium (NULIB). He advanced reasons for the growth of consortia, which include: exponential growth of information; rise in the cost publications; increasing demand by users for better services, and the need to improve resource sharing. In line with this, Maskell (2009) postulated that benefits of consortia to libraries are remarkable. He further noted that consortia have empowered libraries with considerable bargaining power over publishers and have provided libraries with economic advantages. Put differently, a major benefit of consortia is the reduction of cost of acquiring information resources (Martey, 2004). In spite of all these merits the Delta State university system administrator confirmed that his library has not be able to register as a member of this network outfit.

\section{E-book and E-journal stock of the library}

The two librarians agreed that their libraries provide access to e-journals of international standard through the various databases they subscribe to either through individual initiative or network organisations such as the NUNET and NUC virtual library project. It was also observed by the researchers that their subscription was limited to the few databases they have access to. This could also be tied to limited resources 
and high cost of bandwidth. On availability of e-books, both librarians noted that their libraries did not subscribe to any e-book because of copyright laws. As far as research is concerned the academic libraries provide relevant research materials irrespective of formats. Based on the information gathered by the researchers through interview and direct observation of electronic information facilities present in the two university libraries visited. The researchers find out that none of the library understudy met the required standard for a $21^{\text {st }}$ century libraries and a lot have to be done by Nigerian university libraries to enhance library services through einformation.

Table 1: Online data base available in the libraries

\begin{tabular}{|l|l|l|}
\hline Data bases & Delta State University & University of Benin \\
\hline J store & Available & Available \\
\hline BIOMED CENTRAL & Not Available & Available \\
\hline EBCO HOST & Available & Available \\
\hline TEEAL & Not Available & Available \\
\hline HINARI & Not Available & Available \\
\hline CANACADEMY & Not Available & Available \\
\hline OARE & Not Available & Available \\
\hline University Website & Available & Available \\
\hline EGRANARY & Available & Available \\
\hline AGORA & Not Available & Not Available \\
\hline Current content & Not Available & Not Available \\
\hline AGRICOLA & Not available & Not Available \\
\hline DOAJ & Not Available & Available \\
\hline NUC Virtual library & Available & Available \\
\hline
\end{tabular}

Information gathered from the system administrators also establishes that there were some e-journals in sciences, social sciences and related sciences. These include both CD-ROM databases and on-line databases as shown in the table 1 above. It was observed in the interview that university of Benin have more databases with the exception of CANACADEMY which has been acquired but has not be hosted by the library. The situation is different in Delta State University library where the databases were few and at the experimental stages, it was observed that these databases were just at the beginning stages, it was established that Uniben library had functional electronic databases while the e-databases in Delsu library were not adequate enough and at the experimental stages.

\section{Coping Strategies to Frequent changes in Electronic Information Management}

On the methods of coping with the frequent changes in electronic information, the two system administrators unanimously suggested that librarians should be involve in continues training, workshops, research and internet update. They suggested that the library authorities should create conducive environment for librarians and users to excel in technology enhanced library settings.

\section{Problems associated with management of electronic information}

Respond to question on problems of managing electronic resources. The two system librarians identify the following as major problems; insufficient computers, financial constraints, non availability of antivirus software, epileptic power supply, poor capacity building for librarians. This study collaborated with Jagboro (2004), UNIDO (2005), \& Otokunefor (2011), they identify funding for the purchase of electronic resources, poor technological infrastructures, little or no capacity building for librarians and users, irregular power supply, limited bandwidth, very low density of PCs and relatively little awareness of the value of e- resources as barriers to Nigerian university libraries.

\section{Conclusion and Recommendations}

The study noted four major problems associated with electronic information management in the two university libraries under study. These are: inadequate funding for electronic information, insufficient computers, escalating cost of connectivity and attitude of university authorities towards library networking. The study therefore recommends that:

1. Libraries should be encouraged to form a consortium. The basic premise of consortium building is that by working through consortia arrangement, members can achieve more than if they acted alone (Bozimo, 2011).

2. Universities should address the crucial problems of developing local- based information systems within the libraries, capacity building, local content development, developing local area networks and embracing NULIB in its totality.

3. NUC should continue to catalyze other innovations in the development and management of automated systems and services in the Nigerian library system. 
4. Individual libraries must brace up to tackle the challenges that lie ahead in the management of automating their operations.

5. University information managers have to run their non-profit library as dynamic institutions and respond quickly to users' needs.

6. For university libraries to compete with others in developed countries, they have to adapt to frequent changes in electronic information, external environments and technology pressures. The proliferation of electronic information products and services, increasing availability of information processing, storage and communication technologies makes the jobs of information managers all the more interesting (Tonta, 2004).

\section{References}

[1]. Abubakar, B. M. (2010). E. resources for effective academic library service in Nigeria: opportunities and challenges. Journal of the Nigeria library association, Bono state chapter vol.9, no.1 issn :1596-4437

[2]. Adams, L. (1995). Electronic communication technology and development in Africa F/D news bulletin, 45(10),298-306.

[3]. Adams, L. (1997).Content and the web for African development. Journal of information science, 23(1) 91-97.

[4]. Aleraiye, J. T.(2005). Impact of electronic information resources on collection management in Nigeria education sector ,information trends $2: 45-54$

[5]. Bozimo, O. D. (2011). The Nigeria University Libraries consortium: Its Origin, Its Challenges. Nigerian Libraries 44 (2)

[6]. Davenport, T. H. (1997). Information ecology: mastering the information and knowledge environment. New York: oxford university press.

[7]. Ejedafrim, R.F.(2010). Globalization and adoption of information and university libraries; A critical edge in the knowledge age. Pecop journal of the arts and liberal studies. Vol. 2, no.1 and 2 issn 0331-2828.

[8]. Fall, M. (1996). Networking in west African. Offices of international affairs national research council. U S A bridge include. African experience with information and communication technology, 157-176.

[9]. Gbaje, E.S. (2007). Implementing a national virtual library for higher institution in Nigeria. LIBRES; library and information science research electronic journal. 17 (2). Retrend from http://libres.curtinied anl

[10]. Hedstrom, M. (1998). Digital preservation: a time bomb for digital libraries. Retraced from :http://www.uky.edu/kierian/Dl/hedstrom.htw.

[11]. Jagboro, K. O.(2010). A study of Internet Usage in Nigeria Universities: a case study of obafemi Awolowo University, lle-lfe. Retrieved from : http//firstmonday.org/issue 8/3jagboro/index.htm.

[12]. Martey, M. K. (2004). The Future Library Consortium in Ghana. Library Hi Tech News Vol21 no. 2 , $15-19$.

[13]. Maskell, C. (2009). Activities in Academic Libraries: Anticompetitive or in the Public Good? Advances in Library Administration \& Organization. 81-151.

[14]. Onokerhoraye, A. G. (2007). The Ivory Tower has Tilted. Convocation Lecture of Delta State University Abraka.

[15]. Otokunefur, H. O. C. (2011). Implementation of the MacArthur/Carnagie-funded Information and Communication Technology Project in Nigerian University Libraries. Unpublished Doctoral Thesis, Department of Library and Information Science, Delta State University, Abraka, Nigeria.

[16]. Teferna, D. (2004). Knowledge Creation and Dissemination in African Universities with Special Reference to ICT. In P.T. zeleza and A. olukoshi edu. African universities in the twenty first century. Darker: codes RIA 376-399.

[17]. Toffler, A. (1990). Power shift: knowledge, wealth and violence at the edge of the $21^{\text {st }}$ century, New York: Bantam books

[18]. Tonta, y.(2004). Internet and Electronic Information Management. Paper presented at the RTOIMC lecture series on "electronic information management”. Held in sofia Bulgaria, 8- 10 september 2004 and published in RTO-EN_IMC- 002

[19]. UNIDO (2010). Capacity Building for Catching up; Empirical and Policy Dimension. Industrial Development Report 2005. Vienna: United Nations Industrial Development Organization. Retrieved from http;//www.unido.org/en/doc/46385. 